\title{
Organ preservation using a photosynthetic solution
}

Ippei Yamaoka ${ }^{1}$, Takeshi Kikuchi ${ }^{1}$, Tomohiro Arata ${ }^{1}$ and Eiji Kobayashi ${ }^{1,2^{*}}$

\begin{abstract}
Background: Organs harvested from a body lapsing into circulatory deficit are exposed to low $\mathrm{O}_{2} /$ high $\mathrm{CO}_{2}$, and reach a critical point where original functionality after transplantation is unlikely. The present study evaluates the effect of respiratory assistance using Chlorella photosynthesis on preservation of the rat pancreas from the viewpoint of donation after cardiac death (DCD).

Methods: Gas was exchanged through the peritoneum of rats under controlled ventilation with or without Chlorella photosynthetic respiratory assistance. A gas permeable pouch containing Chlorella in solution was placed in the peritoneum and then the space between the pouch and the peritoneum was filled with an emulsified perfluorocarbon gas carrier. Rat DCD pancreases procured $3 \mathrm{~h}$ after cardiac arrest were preserved for $30 \mathrm{~min}$ in a cold or mildly hypothermic environment or in a mildly hypothermic environment with photosynthetic respiratory support. The pancreases were then heterotopically transplanted into rats with STZ-induced diabetes.

Results: Levels of blood oxygen $\left(\mathrm{PaO}_{2}\right)$ and carbon dioxide $\left(\mathrm{PaCO}_{2}\right)$ increased and significantly decreased, respectively, in rats with mechanically reduced ventilation and rats given intraperitoneal photosynthetic respiratory support when compared with those without such support. Transplantation with DCD pancreases that had been stored under photosynthetic respiratory support resulted in the survival of all rats, which is impossible to achieve using pancreases that have been maintained statically in cold storage.
\end{abstract}

Conclusion: Respiratory assistance using photosynthesis helps to improve not only blood gas status in the event of respiratory insufficiency, but also graft recovery after pancreas transplantation with a DCD pancreas that has been damaged by prolonged warm ischemia.

Keywords: Photosynthesis, Donation after cardiac death, Pancreas, Transplantation, Respiratory failure, Warm ischemia, Rat

\section{Background}

Clinical outcomes have considerably improved for patients after organ transplantation, which has become a standard procedure in most developed countries. However, improved clinical outcomes have led to a global shortage of organs, which has encouraged unethical organ trafficking [1]. The value of organs harvested from donation after cardiac death (DCD) donors has been reassessed and applied in the clinical setting [2]. However, oxygen depletion results in the accumulation of acidic products that causes irreversible damage to

\footnotetext{
* Correspondence: eijikoba@jichi.ac.jp

'Otsuka Pharmaceutical Factory, Inc, 115 Kuguhara, Tateiwa, Muya-cho, Naruto, Tokushima 772-8601, Japan

${ }^{2}$ Center for Development of Advanced Medical Technology, Jichi Medical University, 3311-1 Yakushiji, Shimotsuke, Tochigi 329-0498, Japan
}

harvested DCD organs [3]. Static cold storage is a traditional method of organ preservation that arrests cellular metabolism and prevents ATP depletion. However, this does not avoid reperfusion injury to the organ induced by the elevated temperature after transplantation.

Plants and eukaryotic microalgae have permanent intracellular photosynthetic organelles (chloroplasts) for autotrophic growth. On the other hand, various metazoans such as colonial ascidians, molluscs, sponges and cnidarians form an intra- and intercellular algal symbiotic relationship with intracorporeally integrated photosynthetic prokaryotes from the environment or an inherited product $[4,5]$. Incorporated chloroplasts maintain photosynthetic ability and the photosynthetic products are utilized for saccharide synthesis or the anabolism of nitrogen by host organisms [6]. 
We initially attempted to create a symbiotic relationship between rats and a photosynthetic microalga, and removed $\mathrm{CO}_{2}$ from and supplied $\mathrm{O}_{2}$ to the bodies of rats with respiratory insufficiency. We then developed complementary gas exchange between animal respiration and plant photosynthesis to support the respiration of DCD organs and consequently transplanted DCD pancreases obtained at $3 \mathrm{~h}$ after cardiac arrest into rats. This remains impossible after traditional static cold preservation. The present findings should produce a paradigm shift in the concept of traditional preservation and remarkably extend the likelihood of transplantation with organs from DCD donors.

\section{Materials and methods \\ Chlorella photosynthesis}

Oxygen produced by Chlorella photosynthesis was initially examined under various conditions. Chlorella suspensions (Chlorella vulgaris; $1 \times 10^{10}$ cells $/ \mathrm{mL}$; Chlorella Industry, Fukuoka, Japan) diluted 0-, 6.25-, 12.5-, 25-, 50 - and 100-fold were tested under 0, 0.2, 0.6 and $1.8 \mathrm{~g} / \mathrm{dL}$ of $\mathrm{NaHCO}_{3}$. Photosynthetic abilities were also compared under lighting supplied by halogen lamps and by a custom-designed light-emitting diode (LED). We then determined that the optimal conditions for the following experiments from the perspectives of $\mathrm{O}_{2}$ production and $\mathrm{CO}_{2}$ elimination were Chlorella vulgaris, $2.2 \times 10^{8}$ cells $/ \mathrm{mL}$ in $0.6 \mathrm{~g} / \mathrm{dL} \mathrm{NaHCO}_{3}$. Seven LED lights with a luminous flux of 70,000 lux stabilized the temperature of the photosynthetic solution.

\section{Measurements of $\mathrm{O}_{2}$ bubbles produced by Chlorella photosynthesis}

The sizes of $\mathrm{O}_{2}$ bubbles produced in vitro were characterized using scattered laser diffraction that provides the distribution of particle size (Spraytech, Malvern, UK). We then estimated gas exchange capacity between the photosynthetic solution and a carrier emulsion containing 30\% perfluorocarbon ( $\mathrm{PFC}$ ) via an $\mathrm{O}_{2}$-permeable porous membrane (OTP-35H, provided by Otsuka Techno Corporation, Tokushima, Japan). The oxygen concentrations in the PFC carrier were also compared between photosynthesis and oxygen bubbling.

\section{Rat model of respiratory failure}

The committee for animal experiments at the Research and Development Department of Otsuka Pharmaceutical Factory Inc. approved the following experimental procedures. Adult male Sprague-Dawley rats (Charles River Japan, Yokohama, Japan) weighing 490-600 g were housed under constant humidity and temperature $\left(22 \pm 2^{\circ} \mathrm{C}\right)$ under a $12: 12$-h light-dark cycle. An incision of about $5 \mathrm{~cm}$ was cut in the rat abdomen under intravenous (i.v.) anesthesia with sodium pentobarbital (initially $50 \mathrm{mg} / \mathrm{kg}$, supplemented with $25 \mathrm{mg} / \mathrm{kg} / \mathrm{h}$ ) and then the abdominal wall was opened to expose the incision to LED illumination. A vinyl tube (inner diameter, $0.5 \mathrm{~mm}$ ) was inserted into the right carotid artery for blood sampling, and then a 14-gauge plastic tube was placed into the trachea to control ventilation. Heparin (100 IU/kg) was injected i.v. followed by a muscle relaxant (Mioblock; $2 \mathrm{mg} / \mathrm{kg}$ i.v. initially and supplemented with $1 \mathrm{mg} / \mathrm{kg}$ at $75 \mathrm{~min}$ after induction). The rats were immediately connected to a respirator delivering ventilation with $10 \mathrm{~mL} / \mathrm{kg}$ of room air. A temperature controller (NSTC, Neuroscience, Inc., Tokyo, Japan) maintained the rectal temperature at $37^{\circ} \mathrm{C}$ throughout the experiment.

The ventilation rate was maintained at 70 strokes $/ \mathrm{min}$ for the first $15 \mathrm{~min}$ and a $10 \times 10 \mathrm{~cm}$ porous pouch containing $100 \mathrm{~mL} / \mathrm{kg}$ of photosynthetic Chlorella vulgaris $2.2 \times 10^{8}$ cells $/ \mathrm{mL}$ in $0.6 \mathrm{~g} / \mathrm{dL} \mathrm{NaHCO}_{3}$ was placed in the rat peritoneal cavity. The rats were then assigned to the following groups ( $n=6$ per group): immediate illumination via LED to start photosynthesis (light, L) or not (Dark, D; Controls) in the presence or absence of PFC emulsion [L-PFC (+) or L-PFC (-) and D-PFC (+) and D-PFC (-), respectively]. At $45 \mathrm{~min}$ after implantation with a pouch containing Chlorella, the 30\% PFC-emulsion diluted with normal saline was channelled between the abdominal wall and the $\mathrm{O}_{2}$-permeable membrane at a dose of $50 \mathrm{~mL} / \mathrm{kg}$ in the L-PFC (+) and D-PFC (+), but not in the L-PFC (-) and D-PFC (-) groups. Oxygen and carbon dioxide levels in the heparinized blood in these rats were monitored using Model $348 \mathrm{pH} /$ blood gas analyzer (Chiron Diagnostics, Halstead, UK) at 15-min intervals.

\section{Pancreatic transplantation $\mathbf{3} \mathrm{h}$ after cardiac arrest}

Donor male LEW rats (Charles River Laboratories Japan Inc., Yokohama, Japan) weighing 200-300 g were fasted from the day before transplantation. Recipient rats were intravenously administered with $50 \mathrm{mg} / \mathrm{kg}$ of streptozotocin (Sigma-Aldrich Japan, Tokyo, Japan) in citric acid buffer 3 days before transplantation. All rats had glycemic levels of $\geq 300 \mathrm{mg} / \mathrm{dL}$.

Cardiac arrest was induced in donor rats by the inhalation of excess diethyl ether and then the rats remained at room temperature for $3 \mathrm{~h}$. The pancreas was removed via laparotomy along with the spleen and the common bile duct was ligated. The sheath of an $18 \mathrm{G}$ Surflow cannula (Terumo, Tokyo, Japan) was inserted into the abdominal aorta of the pancreas, which was then irrigated with $200 \mu \mathrm{L}$ of $10 \%$ heparin in normal saline at room temperature. The DCD rat pancreases were then preserved in $1.5 \mathrm{~g} / \mathrm{dL}$ of hemoglobin derived from bovine blood (Sigma, Tokyo, Japan) in an organ preservation solution (ETK, Otsuka Pharmaceutical Factory Inc., Tokushima, Japan) for $30 \mathrm{~min}$ at $4^{\circ} \mathrm{C}$ (cold), $22^{\circ} \mathrm{C}$ (mildly 
hypothermic) or at $22^{\circ} \mathrm{C}$ with photosynthetic respiratory support. Photosynthesis proceeded in the Chlorella solution $(50 \mathrm{~mL})$ inside the gas-permeable pouch that was immersed in photosynthetic preservation solution at $\mathrm{PaO}_{2}>300 \mathrm{mmHg}$.

Recipient rats were anesthetized by the inhalation of diethyl ether and the right side of the neck was incised. The right jugular vein and carotid artery were separated, and then cuffs (Terumo, Tokyo, Japan) comprising the sheaths of the $20 \mathrm{G}$ and $16 \mathrm{G}$ Surflow catheters were attached to each, respectively. The abdominal aorta was anastomosed to the carotid artery, the portal vein was anastomosed to the jugular vein and the pancreas graft was reperfused. Thereafter, the spleen was resected from the pancreas graft, and the neck skin was closed with a continuous suture. Normal saline $(5 \mathrm{~mL})$ was intradermally administered immediately after surgery, blood was collected $4 \mathrm{~h}$ later and $2 \mathrm{~mL}$ of $25 \%$ glucose was intraperitoneally administered thereafter.

\section{Tissue $\mathrm{O}_{2}$ measurements}

Tissue oxygen $\left(\mathrm{PaO}_{2}\right)$ levels were determined using an $\mathrm{O}_{2}$ electrode system (Oxy Lab; Oxford Optronix Ltd., Oxford, UK). Organs isolated from rats $3 \mathrm{~h}$ after cardiac arrest were immersed in organ preservation solution (ETK, Otsuka Pharmaceutical Factory Inc., Tokushima, Japan) containing $1.5 \mathrm{~g} / \mathrm{dL}$ hemoglobin (Hb-ETK) from bovine blood (Sigma, Tokyo, Japan) at $22^{\circ} \mathrm{C}$ under photosynthesis or $\mathrm{O}_{2}$ bubbling or at $4^{\circ} \mathrm{C}$ without either treatment. The Chlorella was substituted with saline and $\mathrm{O}_{2}$ inspired inside the bag was bubbled.

\section{Statistical analysis}

Values for each group are presented as means \pm SD. Differences among the groups were analyzed by two-way repeated measures and one-way ANOVA or $\chi^{2}$ test, and Tukey's post hoc tests if appropriate. Statistical significance was set at $p<0.05$.

\section{Results and discussion}

Complementary gas exchanges between rats and Chlorella We first measured the $\mathrm{O}_{2}$ bubbles produced during Chlorella photosynthesis. Air bubbles of various sizes $(2-1000 \mu \mathrm{m})$ were found in the photosynthetic solution (Figure 1). Particles $(2-4 \mu \mathrm{m})$ of $\mathrm{O}_{2}$ bubbles were detected on the surface of Chlorella 5 min after starting photosynthesis (Figure 1D). The gas gradually increased and $\mathrm{O}_{2}$ bubbles of about $700 \mu \mathrm{m}$ in diameter dominated the particles that appeared in the photosynthetic solution 20 min after LED illumination. The photosynthetic reaction precludes the need for specialized foaming equipment to generate oxygenated micro-bubbles or nano-bubbles [7]. We compared the flow of gases generated by Chlorella photosynthesis and by $\mathrm{O}_{2}$-bubbling through the gas- permeable membrane. Oxygen partial pressure $\left(\mathrm{PaO}_{2}\right)$ gradually increased to $300-600 \mathrm{mmHg}$ within $30 \mathrm{~min}$ of either solution being placed on the other side of the oxygen production system, indicating that $\mathrm{O}_{2}$ can penetrate the membrane (data not shown).

Some silicone oils and fluorocarbon solutions equilibrated with $\mathrm{O}_{2}$ gas support mammalian respiration through the lungs [8]. A gas-permeable pouch containing a photosynthetic solution of Chlorella implanted into the peritoneum of anesthetized rats with a mechanically reduced respiratory rate was illuminated using an LED light to start photosynthesis. Figure 2A summarizes our in vivo model of respiratory failure with a low frequency of respiration. The $\mathrm{PaO}_{2}$ decreased in the blood and $\mathrm{PaCO}_{2}$ increased after reducing the ventilation rate. However, the $\mathrm{PaO}_{2}$ of the rats under photosynthetic respiratory assistance gradually increased, whereas the $\mathrm{PaCO}_{2}$ decreased after filling the space between the abdominal wall and the gas-permeable membrane with the perfluorocarbon (PFC) gas-carrier (Figure $2 \mathrm{~B}$ and $\mathrm{C}$ ). Photosynthesis did not affect $\mathrm{PaO}_{2}$ and $\mathrm{PaCO}_{2}$ unless PFC was injected into the space (data not shown). These results show that adding an aqueous gas carrier to fill the space between a mammalian abdomen and Chlorella within a gas-permeable environment results in complementary gas exchange between different species. Studies of artificial lungs have examined sites other than lungs, particularly direct injection of $\mathrm{O}_{2}$ gas to the peritoneum [9] or the peritoneal perfusion of liquids containing $\mathrm{O}_{2}$ [10]. We believe that we have pioneered the use of a photosynthetic microalga to remove of $\mathrm{CO}_{2}$ from, and supply $\mathrm{O}_{2}$ to the whole body of rats with respiratory insufficiency.

\section{Respiratory assistance to DCD pancreases using Chlorella photosynthesis}

Respiratory assistance using photosynthesis might also be applicable to the preservation or revival of $\mathrm{O}_{2}$ depleted and $\mathrm{CO}_{2}$ - enriched organs with circulatory failure harvested from DCD donors. We established a respiratory support system to reverse this process in organs (Figure 3). The $\mathrm{PaO}_{2}$ of the rat pancreas retrieved $3 \mathrm{~h}$ after cardiac arrest was essentially $0 \mathrm{mmHg}$ after cold static preservation (Figure 4A). The $\mathrm{PaO}_{2}$ increased in the DCD pancreas assisted by respiration using photosynthesis for $30 \mathrm{~min}$ at $22^{\circ} \mathrm{C}$. The $\mathrm{PaO}_{2}$ also increased over a period of $30 \mathrm{~min}$ via direct bubbling from an oxygen cylinder in the positive control organ for oxygenation. These results indicated that preservation under photosynthetic respiratory assistance causes oxygenation in organs even after $3 \mathrm{~h}$ of cardiac arrest in a fashion similar to that of general oxygenation via direct $\mathrm{O}_{2}$ infusion. The mechanisms underlying the penetration of organs with $\mathrm{O}_{2}$ remains to be determined, but 15\% 

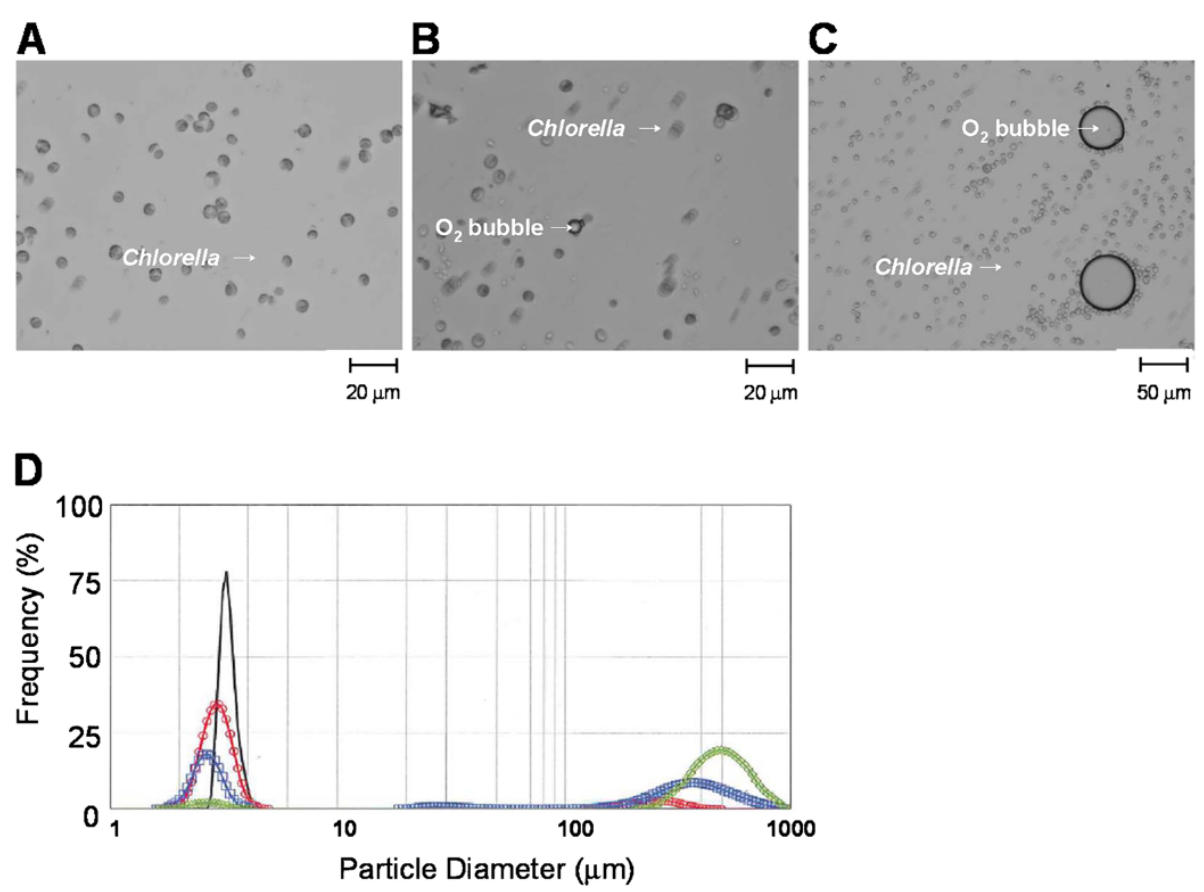

Figure 1 Light microscope images of oxygen $\left(\mathrm{O}_{2}\right)$ bubbles generated by photosynthesis in Chlorella (A-C). D: Distribution of frequencies of volume occupied by each particle in photosynthetic solution before (black line) and at 5 (red), 10 (blue), and 20 (green) min after light-emitting diode illumination. The peak before illumination indicates Chlorella particles (black line).

oxygenation of the total volume of the pancreas achieved using the two layer method (TLM) is sufficient to maintain ATP levels in islet cells damaged by warm ischemic injury [11]. Therefore, oxygenation by photosynthesis would improve the function of organs exposed to warm ischemia and recover grafts exposed to prolonged warm ischemia.

We then evaluated the outcomes of providing respiratory assistance to DCD organs after transplantation. Pancreases removed from rats $3 \mathrm{~h}$ after cardiac arrest were preserved under either traditional static cold storage $\left(4^{\circ}\right.$ C) or under mildly hypothermic $\left(22^{\circ} \mathrm{C}\right)$ conditions with or without respiratory assistance, and then transplanted into rats with STZ-induced diabetes mellitus. We previously evaluated the ATP contents of pancreases obtained from Luc Tg rats [12] at 1 or $5 \mathrm{~h}$ after cardiac arrest. Since the luciferase gene with the Rosa 26 promoter is chromosomally integrated and expressed in all organs of this rat strain, changes in ATP concentrations in harvested organs can be determined from chips of sliced tissues obtained from these rats. The ATP contents of the pancreas substantially decreased at $1 \mathrm{~h}$ after cardiac arrest but decreased to minimal levels at $5 \mathrm{~h}$ thereafter. We also clarified that rats transplanted with a pancreas at $3 \mathrm{~h}$ after cardiac arrest immediately die, whereas those transplanted within 1 or $2 \mathrm{~h}$ thereafter do not. These data imply that reducing pancreatic ATP levels determines the feasibility of transplantation [13].

Five of the six rats that received organs that were traditionally preserved in a cold environment for $30 \mathrm{~min}$ after isolation died at 3 to $5 \mathrm{~h}$ after transplantation, whereas all rats that received organs preserved under photosynthetic respiratory assistance survived for over 1 week (Figure $4 \mathrm{~B}$ ). One rat each that was transplanted with an organ preserved at $22^{\circ} \mathrm{C}$ without photosynthetic support died within 5 and $7.5 \mathrm{~h}$ and the survival rate did not significantly differ from that of animals transplanted with organs that had been traditionally preserved at $4^{\circ} \mathrm{C}$.

Hyperglycemia and hypoglycemia (glucose $>600$ and $<20 \mathrm{mg} / \mathrm{dL}$, respectively) were identified in two of three animals at $4 \mathrm{~h}$ after transplantation with traditionally preserved organs. In contrast, none of the rats transplanted with organs preserved under photosynthesis developed hyperglycemia $\geq 180 \mathrm{mg} / \mathrm{dL}$. However, three of six rats transplanted with organs preserved at $22^{\circ} \mathrm{C}$ without photosynthesis became hyperglycemic (glucose concentration $\geq$ $180 \mathrm{mg} / \mathrm{dL}$ ). Plasma insulin levels were not examined in the present study, but early hyperinsulinism caused by irreversible ischemia/reperfusion injury of grafts indicates poor outcomes such as death attributable to hypoglycemia $[14,15]$. We postulated that the cause of the death after transplantation is attributable to ischemic damage that 

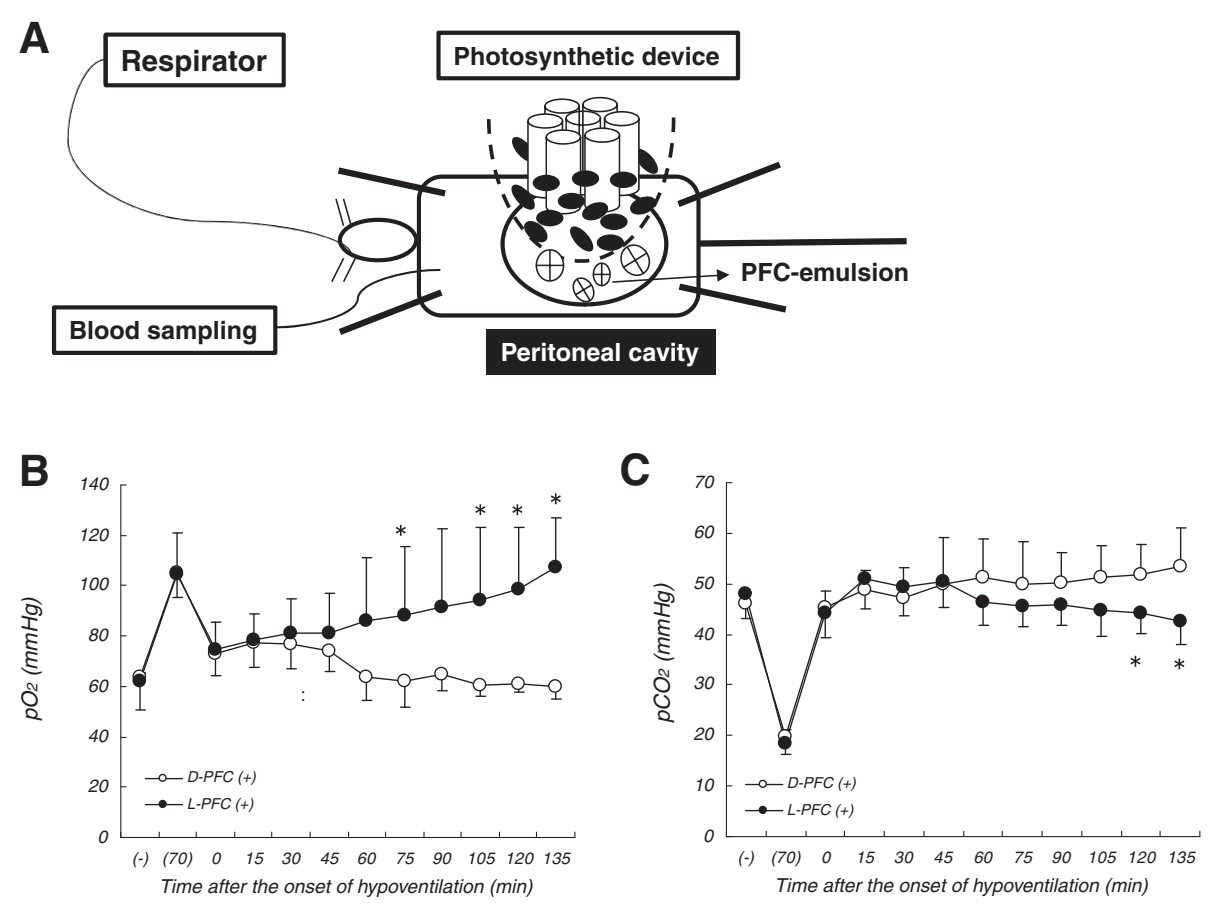

Figure 2 Schema of photosynthetic respiratory support through the peritoneum (A). Arterial blood gas measurements $\left(\mathrm{PO}_{2}, \mathbf{B} ; \mathrm{PCO}_{2}, \mathbf{C}\right)$ in anesthetized rats under hypoventilation with $(\bullet)$ or without photosynthesis $(0) ;(-)$ and $(70)$, periods before and 15 min after 70 strokes/min of ventilation, respectively. Space between rat abdomen and gas-permeable pouch filled with 30\% perfluorocarbon emulsion 45 min after starting hypoventilation $(0 \mathrm{~min})$. Values are means \pm S.D $(n=6) .{ }^{*}$ Significant difference $(P<0.05)$.

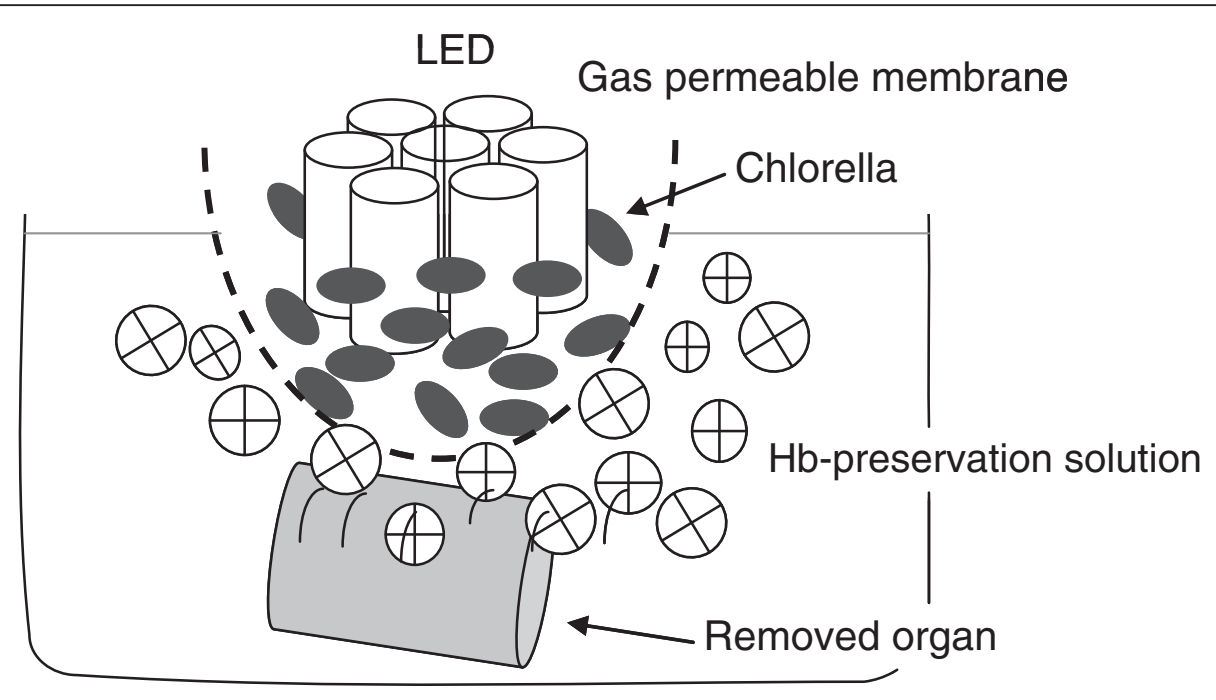

Figure 3 System for photosynthetic respiratory assistance of harvested organs. Pancreases isolated from donor rats at $3 \mathrm{~h}$ after cardiac arrest are placed in preservation solution containing $1.5 \mathrm{~g} / \mathrm{dL}$ bovine hemoglobin. An oxygen permeable pouch containing Chlorella in $50 \mathrm{~mL}$ of solution $\left(0.6 \mathrm{~g} / \mathrm{dL} \mathrm{NaHCO}_{3}\right)$ is immersed in $50 \mathrm{~mL}$ of preservation solution illuminated with an immersible custom-designed device comprising seven LED lights (70,000 lux) for 30 min. Oxygen generated from Chlorella photosynthesis is transferred to preservation solution via permeable film. 

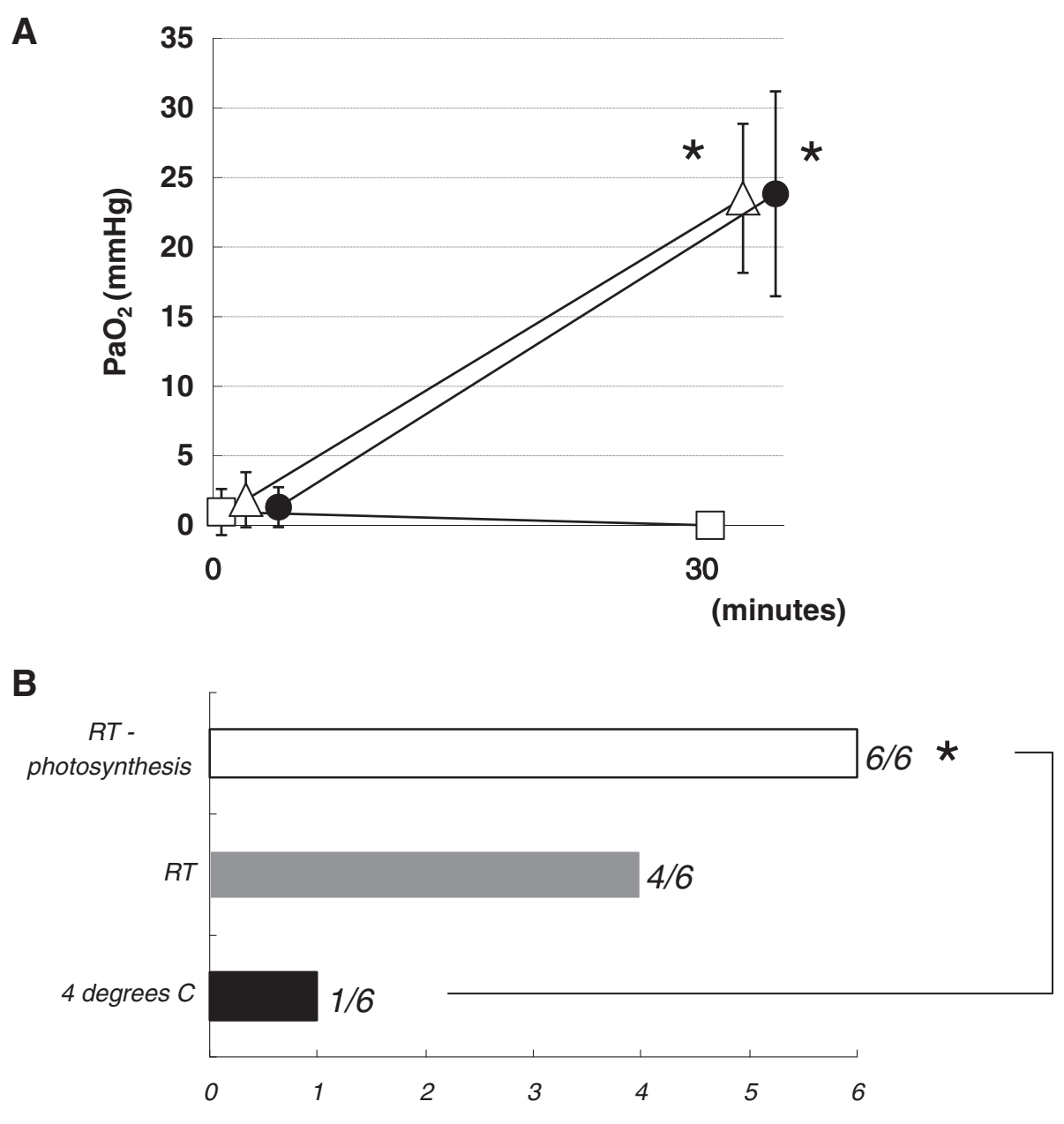

The number of surviving rats

Figure 4 Changes in partial $\mathrm{O}_{2}(\mathrm{mmHg})$ of rat pancreas isolated $3 \mathrm{~h}$ after cardiac arrest and immersed in preservation solution containing bovine hemoglobin (A). Pancreas immersed in preservation solution containing bovine hemoglobin without further manipulation at $4^{\circ} \mathrm{C}, \square$; respiratory assistance through photosynthesis at $22^{\circ} \mathrm{C}, \nabla$; oxygen bubbling at $22^{\circ} \mathrm{C}$, $\bullet$. Both respiratory assistance systems were placed on other side of the pancreas via a gas permeable membrane. Values are means $\pm S D ; n=3$. ${ }^{*}$ Significant difference from storage without further manipulation $(p<0.05)$. (B). Effect of photosynthetic respiratory assistance on survival rates of rats ectopically transplanted with pancreases obtained from rats at $3 \mathrm{~h}$ after cardiac arrest. Survival rates of recipient rats for up to 7 days after transplantation were compared after 30 min of immersion in preservation solution at $4^{\circ} \mathrm{C}$ or at room temperature $\left(\mathrm{RT} ; 22^{\circ} \mathrm{C}\right)$ with or without photosynthesis before transplantation. ${ }^{*}$ Significant difference from storage at $4^{\circ} \mathrm{C}(p<0.05)$.

causes early high insulin release from a non-functioning pancreas and subsequent hypoglycemia.

Static cold storage is currently the most popular form of preservation in routine clinical practice. Although simple and effective, whether this method can prevent the deterioration of organ quality is questionable when increasing numbers of organs are becoming harvested from older, more marginal donors, including DCD donors [16]. In fact, even a short period of cold exposure $(0.5 \mathrm{~h})$ significantly deteriorates the favourable impact of mildly hypothermic immersion. In another set of experiments, we constructed a system in which photosynthesis proceeded in a preservation solution maintained at $4^{\circ} \mathrm{C}$, and then the pancreas was transplanted into diabetic rats $(n=6)$. Three rats died but the one survivor had aberrant glucose control (glucose $>600 \mathrm{mg} / \mathrm{dL}$ ). These results imply that preservation using respiratory assistance requires an optimal temperature. The viability of organ donors from harvest to transplantation is crucial for maintaining optimal graft function and impacts survival rates [17]. These results indicate that the outcomes of pancreatic transplantation would improve if oxygen generated by photosynthesis were provided to tissues with an increased oxygen demand caused by preservation at room temperature. 
Preservation using photosynthesis might have several limitations when applied to the clinical setting or to larger animals. The question would arise as to whether this technique could provide adequate oxygenation and deeper $\mathrm{O}_{2}$ penetration into solid and/or large organs as in TLM, in which some discrepancies in its benefits are apparent between small and large animal experimental models $[18,19]$. Furthermore, even in small animal models, oxygen delivery is inadequate for organs with dense and robust capsules such as the liver and kidneys [20]. Therefore, combination with other methods such as automated perfusion with immersion might improve the oxygenation of solid and larger organs [21], although this would be rather complex and difficult for routine application.

Some populations of eukaryotes can form symbiotic connections [6,22]. Artificial manipulation has never enabled a living entity or its zooblast to coexist with photosynthetic microorganisms or its organelles. Furthermore, concomitant gas-exchange between plants and animals has not, to the best of our knowledge, been reported. Therefore, we discovered that complementary respiration through photosynthesis can be achieved by artificial symbiosis between a microalga and a mammal or its organs.

\section{Competing interests}

E. K. is a special advisor to Otsuka Pharmaceutical Factory Inc. The other authors declare no competing financial interests.

\section{Acknowledgements}

We thank Mr. Hiroki Akaishi for excellent technical assistance.

\section{Authors' contributions}

IY designed the study, performed the study in vivo and in vitro, collected data, performed statistical analysis, interpreted the findings and drafted the manuscript. TK performed the study in vivo and collected data. TA performed the study in vitro and collected data. EK designed and coordinated the study and helped to draft the manuscript and interpret data. All authors read and approved the final manuscript.

Received: 18 October 2011 Accepted: 24 April 2012

Published: 24 April 2012

\section{References}

1. Huang J, Mao Y, Millis JM: Government policy and organ transplantation in China. Lancet 2008, 372:1937-1938.

2. Delimiting death. Nature 2009, 461:570.

3. Kallerhoff M, Hölscher M, Kehrer G, Kläss G, Bretschneider HJ: Effects of preservation conditions and temperature on tissue acidification in canine kidneys. Transplantation 1985, 39:485-489.

4. Lewin RA: Prochloron and the theory of symbiogenesis. Ann N Y Acad Sci 1981, 361:325-329

5. Margulis L: Symbiosis in cell evolution. New York: Freeman WH; 1981:419.

6. Rumpo EM, Farahad PD, Manhart JR, Lee J: The Kleptoplast. In The structure and function of plastids. Edited by Wise RR, Hoober JK. Netherland: Springer; 2007:451-473.

7. Gerber F, Waton G, Krafft MP, Vandamme TF: Long lived microbubbles for oxygen delivery. Artif Cells Blood Substit Immobil Biotechnol. 2007, 35:119-124.

8. Clark LC Jr, Gollan F: Survival of mammals breathing organic liquids equilibrated with oxygen at atmospheric pressure. Science 1966, 24:1755-1756
9. Awad JA, Brassard A, Caron WM: Intraperitoneal oxygenation. An experimental study in dogs. Int Surg 1970, 53:162-166.

10. Klein J, Faithfull NS, Salt PJ, Trouwborst A: Transperitoneal oxygeneration with fluorocarbon. Anesth Analg 1986, 65:734-738.

11. Brandhorst D, Iken M, Bretzel RG, Brandhorst H: Pancreas storage in oxygenated perfluorodecalin does not restore post-transplant function of isolated pig islets pre-damaged by warm ischemia. Xenotransplantation 2006, 13:465-470.

12. Hakamata Y, Murakami T, Kobayashi E: "Firefly rats" as an organ/cellular source for long-term in vivo bioluminescent imaging. Transplantation 2006, 81:1179-1184.

13. Kuroda Y, Fujino Y, Morita A, Ku Y, Saitoh Y: Correlation between high adenosine triphosphate tissue concentration and good posttransplant outcome for the canine pancreas graft after preservation by the twolayer cold storage method. Transplantation 1991, 52:989-991.

14. Cerra FB, Adams JR, Eggert DE, Eilert JB, Bergan JJ: Pancreatic function after normothermic ischemia. II. Cadaveric transplantation. Am J Surg 1970, 120:693-696.

15. Basadonna G, Choi-Lee H, Chao CT, Swanson C, Morgan M, Wong A, Curry $D$, Perez R: Effect of warm ischemia on insulin secretion in non-heartbeating donors. Transplant Proc 1995, 27:2793-2794.

16. Moers C, Smits JM, Maathuis MH, Treckmann J, van Gelder F, Napieralski BP, van Kasterop-Kutz M, van der Heide JJ, Squifflet JP, van Heurn E, Kirste GR, Rahmel A, Leuvenink HG, Paul A, Pirenne J, Ploeg RJ: Machine perfusion or cold storage in deceased-donor kidney transplantation. N Engl J Med 2009, 360:7-19.

17. Maathuis $\mathrm{MH}$, Leuvenink HG, Ploeg RJ: Perspectives in organ preservation Transplantation 2009, 83:1289-1298.

18. Hosgood SA, Mohamed IH, Nicholson ML: The two layer method does not improve the preservation of porcine kidneys. Med Sci Monit 2011, 17: BR27-BR33.

19. Papas KK, Hering BJ, Guenther L, Rappel MJ, Colton CK, Avgoustiniatos ES: Pancreas oxygenation is limited during preservation with the two-layer method. Transplant Proc 2005, 37:3501-3504.

20. Avgoustiniatos ES, Hering BJ, Papas KK: The rat pancreas is not an appropriate model for testing the preservation of the human pancreas with the two-layer method. Transplantation 2006, 81:1471-1472.

21. Maathuis $M H$, Manekeller S, van der Plaats A, Leuvenink HG, 't Hart NA, Lier $A B$, Rakhorst G, Ploeg RJ, Minor T: Improved kidney graft function after preservation using a novel hypothermic machine perfusion device. Ann Surg 2007, 246:982-988.

22. Teugels B, Bouilon S, Veuger B, Middelburg JJ, Koedam N: Kleptoplasts mediate nitrogen acquisition in the sea slug Elysia viridis. Aquat Biol 2008, 4:15-21.

doi:10.1186/2047-1440-1-2

Cite this article as: Yamaoka et al: Organ preservation using a photosynthetic solution. Transplantation Research 2012 1:2

\section{Submit your next manuscript to BioMed Central and take full advantage of:}

- Convenient online submission

- Thorough peer review

- No space constraints or color figure charges

- Immediate publication on acceptance

- Inclusion in PubMed, CAS, Scopus and Google Scholar

- Research which is freely available for redistribution 